\title{
PERFORMANCE OF RADIANT COOLING SYSTEM INTEGRATED WITH ICE STORAGE
}

Masafumi Kondo $^{1}$, Naoko Matsuki ${ }^{2}$, Yukio Nakano ${ }^{3}$, Toshiyuki Miyanaga ${ }^{3}$, Tatsuo Oka ${ }^{4}$

\author{
${ }^{1}$ Department of Architecture, Utsunoiya University, Utsunomiya + 321-8585 - Japan \\ ${ }^{2}$ Maeda Engineering Consultants, Nagoya + 453-0801 - Japan \\ ${ }^{3}$ Komae Research Laboratory, Central Research Institute of Electric Power Industry, Komae + 201-8511 - Japan \\ ${ }^{4}$ Prof, Department of Architecture, Utsunomiya University, Utsunomiya + 321-8585 - Japan
}

\section{ABSTRACT}

The purpose of this study is designing a hybrid system which is a combination of radiant cooling and low temperature air conditioning integrated with ice storage system. Also this evaluates the performance of the system.

We compared energy amount with annual operating costs of conventional air conditioning system and this radiant air conditioning system.

\section{INTRODUCTION}

Electricity consumption by air conditioning accounts for some $50 \%$ of the total power consumption in office building. It is a primary factor in the increase of the peak in power demand, particularly in summer. In this regard, aiming to level the load, both the power industry and the government are making efforts to promote thermal storage system for air conditioning. Generally due to the fact that an air conditioning system with thermal storage requires a higher initial investment, it stands at a disadvantage on an initial cost basis when compared with a conventional air conditioning system. Therefore, in order to promote thermal storage system, we must develop a better secondary air conditioning system which can make the most of the features of ther- mal storage. A comprehensive evaluation of such a system is also needed to verify both its advantages and disadvantages fairly.

In this study two systems are combined, namely, the ice storage system effective for load leveling, and the radiant cooling system for producing a better thermal environment. Thus, we propose an air conditioning system which incorporates the merits of both systems to the maximal extent. We attempt to comprehensively evaluate the system from the perspectives of load leveling, energy saving, and economy.

\section{EXPERIMENTS OF PERFORMANCE EVALUATION}

\subsection{METHODS}

\subsubsection{Chamber}

We designed a chamber in which the temperature and humidity could be controlled (fig.1). Measurements of the thermal environment and experiments with subjects were carried out in the chamber. Radiant cooling panel using chilled water as a refrigerant is set up, and the temperature of chilled water can be controlled. Room temperature and humidity are controlled by air conditioning.

Table 1 indicates environmental parameters from 8

Table 1 Environmental Parameters of 8 cases And Data of Measurements

\begin{tabular}{|c|c|c|c|c|c|c|c|c|c|c|}
\hline & \multicolumn{4}{|c|}{ Parameters } & \multicolumn{6}{|c|}{ Data of Measurements } \\
\hline No. & System & $\begin{array}{c}\text { Room } \\
\text { Temperature } \\
{\left[{ }^{\circ} \mathrm{C}\right]}\end{array}$ & $\begin{array}{c}\text { Humidity } \\
{[\%]}\end{array}$ & $\begin{array}{c}\text { Ceiling Surface } \\
\text { Temperature } \\
{\left[{ }^{\circ} \mathrm{C}\right]}\end{array}$ & $\begin{array}{c}\text { Room } \\
\text { Temperature } \\
{\left[{ }^{\circ} \mathrm{C}\right]}\end{array}$ & $\begin{array}{c}\text { Humidity } \\
{[\%]}\end{array}$ & $\begin{array}{c}\text { Ceiling Surface } \\
\text { Temperature } \\
{\left[{ }^{\circ} \mathrm{C}\right]}\end{array}$ & $\begin{array}{l}\text { MRT } \\
{\left[{ }^{\circ} \mathrm{C}\right]}\end{array}$ & $\begin{array}{l}\mathrm{OT} \\
{\left[{ }^{\circ} \mathrm{C}\right]}\end{array}$ & \begin{tabular}{|c} 
Air \\
Velocity \\
{$[\mathrm{m} / \mathrm{s}]$}
\end{tabular} \\
\hline 1 & \multirow{3}{*}{$\begin{array}{c}\text { Convectional } \\
\text { Air } \\
\text { Conditioning }\end{array}$} & 26 & 60 & & 25.8 & 50.8 & 28.5 & 26.4 & 26.1 & 0.12 \\
\hline 2 & & 28 & 40 & & 27.6 & 42.6 & 29.9 & 27.9 & 27.8 & 0.13 \\
\hline 3 & & 26 & 50 & & 25.1 & 51.6 & 27.7 & 25.6 & 25.4 & 0.11 \\
\hline 4 & \multirow{5}{*}{$\begin{array}{l}\text { Radiant } \\
\text { Cooling } \\
\text { System }\end{array}$} & \multirow{3}{*}{28} & \multirow{3}{*}{40} & 20 & 27.3 & 42.8 & 20.2 & 26.5 & 26.9 & 0.08 \\
\hline 5 & & & & 22 & 27.9 & 42.7 & 22.0 & 27.2 & 27.5 & 0.08 \\
\hline 6 & & & & 24 & 27.9 & 42.3 & 23.5 & 27.4 & 27.6 & 0.08 \\
\hline 7 & & 29 & 40 & 20 & 29.0 & 42.6 & 20.7 & 28.0 & 28.5 & 0.09 \\
\hline 8 & & 28 & 50 & 20 & 28.1 & 47.4 & 20.4 & 27.1 & 27.6 & 0.09 \\
\hline
\end{tabular}


cases. Test case from 1 to 3 are carried out under convectional air conditioning system(convectional AC), 4 to 8 are carried out under radiant cooling systems. In this report, convectional AC means conventional air conditioning system.

\subsubsection{Experiments with subjects}

Methods of experiments with subjects are as follows ; 1. 2 subjects per experiment enter the chamber

2. experiments begin 30 minutes after entering the chamber

3. subjects fill out questionnaires for 10 minutes, in total 7 times

4. Each case consists of 12 subjects

Table 2 presents scales of comfort and thermal sensation on the questionnaires. Thermal environments are measured during experiments with subjects.

\subsection{RESULTS OF EXPERIMENTS}

\subsubsection{Room environments}

Table 1 presents a list of the average conditions maintained during each of the 8 tests on radiant cooling systems or convectional AC.

Air velocity under radiant cooling is lower than under convectional air conditioning. Under convectional AC, mean radiant temperature (MRT) is higher than room temperature. This is because the ceiling surface temperature is higher. On the other hand, under radiant cooling systems, effect of the cooling panel makes MRT more than $0.5^{\circ} \mathrm{C}$ lower than room temperature. Difference of operative temperature (OT) between case 1 and case 4 is $0.8^{\circ} \mathrm{C}$.

Fig. 2 presents the vertical temperature distribution. Top and bottom difference of air temperature is large, and ceiling surface temperature and floor surface temperature are high in Convection. Top and bottom difference of air temperature is small, and in addition to ceiling surface temperature, floor surface temperature is high, too.

Fig. 3 presents the pictures of thermal camera in case of theraml environment.

In fig.3(a), there are many spots. In fig.3(b), tempareture distribution is stable, and Lighting Load is processed enough, and wall side temperature is lowered by effect of mutural radiation.
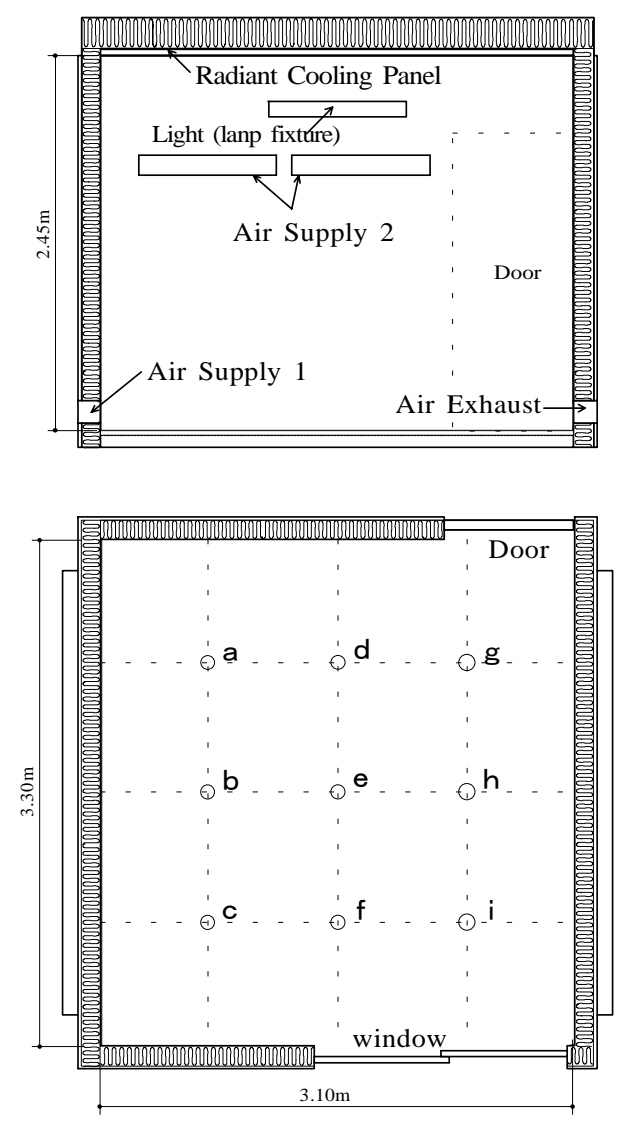

Fig. 1 Chamber

Table2 7-Points Scale of Comfort

And Thermal Sensation

\begin{tabular}{|r|c||c|}
\hline & Comfort & Thermal Sensation \\
\hline+3 & Very Comfortable & Hot \\
\hline+2 & Comfortable & Slight Hot \\
\hline+1 & Slight Comfortable & Warm \\
\hline 0 & Neutral & Neutral \\
\hline-1 & Slight Uncomfortable & Cool \\
\hline-2 & Uncomfortable & Slight Cool \\
\hline-3 & Very Uncomfortable & Cold \\
\hline
\end{tabular}

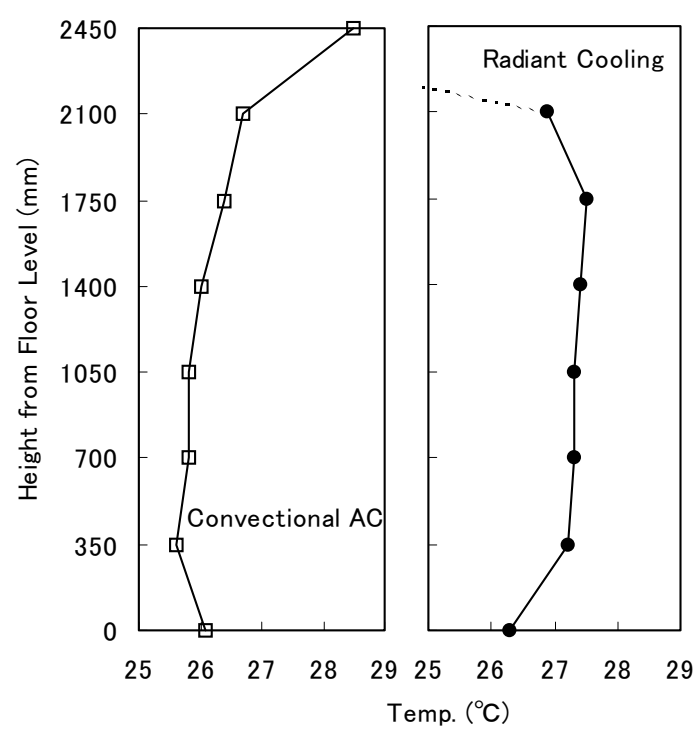

Fig. 2 Vertical temperature distribution 


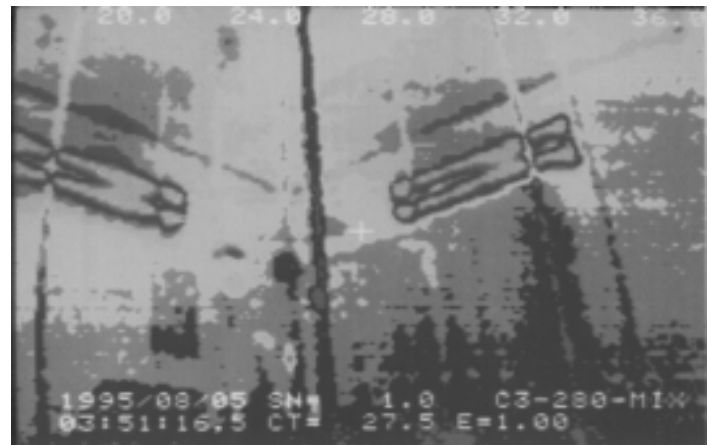

(a) Convectional AC

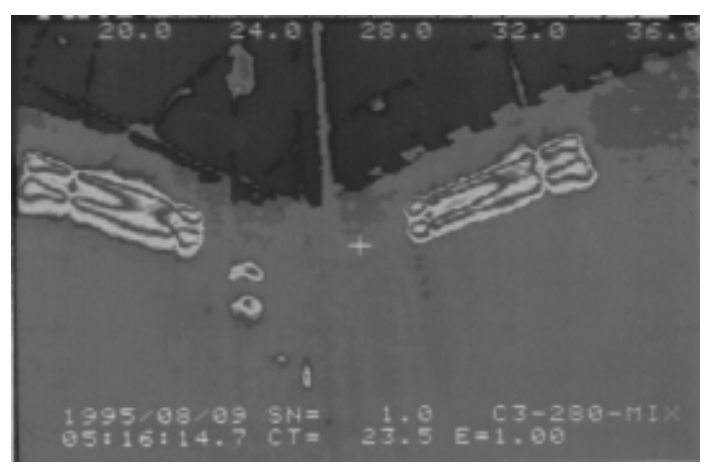

(b) Radiant Cooling

Fig.3 Pictures of Thermal Camera

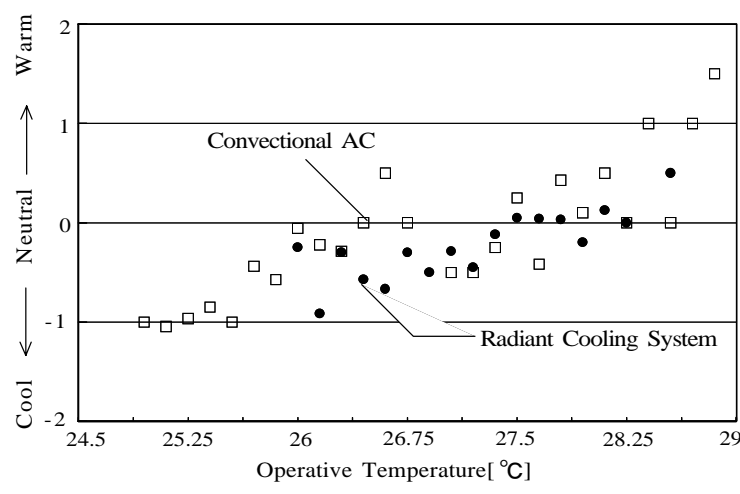

Fig. 4 Relation between OT and Thermal Sensation

Fig.4 presents the relation between OT and Thermal Sensation Sense, and fig.5 presents the relation between OT and comfort. In fig.4, there is little difference between the cooling system in Thermal Sensation Sense. In fig.5, most comfortable temperature under convectional $\mathrm{AC}$ is $25.75 \sim 26.9^{\circ} \mathrm{C}$. On the other hand, under radiant cooling system temperature ranging between $26.6 \sim 26.9^{\circ} \mathrm{C}$ can produce the same comfort as convectional AC. It is shown that radiant cooling systems at OT $26.0 \sim 26.6^{\circ} \mathrm{C}$ produce more comfort than any other system.

\subsection{CONSIDERATION}

The reason why radiant cooling systems can produce more comfort than convectional AC at equal OT is due to 1$)$ the effect of radiation from the surface of the subject (skin-clothing) to the ceiling panel, and 2) the effect that low humidity makes human environmental temperature lower.

Equivalent OT to the most comfortable OT under convectional AC according to the experimental results is $27.0^{\circ} \mathrm{C}$. We estimate the optimum OT is as follows; $26.5^{\circ} \mathrm{C}$ if taking much of human comfort, $27.0^{\circ} \mathrm{C}$ if tak-

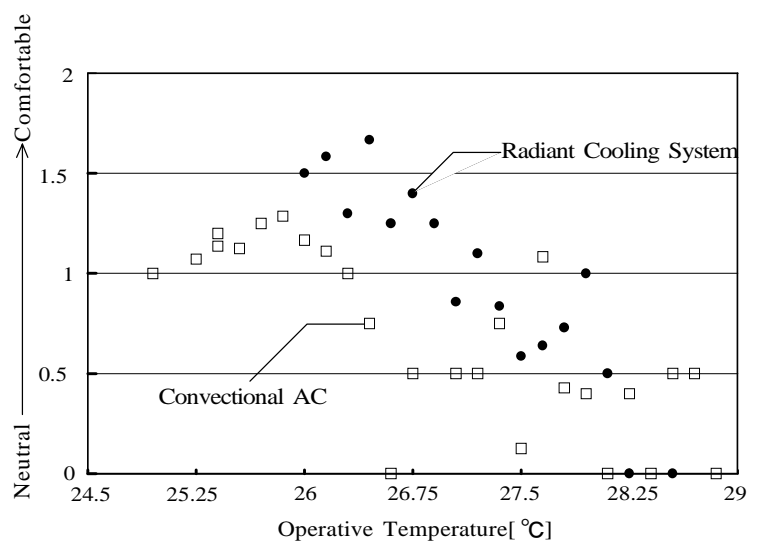

Fig. 5 Relation between OT and Comfort

ing into consideration energy-saving. Room condition at OT $27.0^{\circ} \mathrm{C}$ is supplied at room temperature $27.5^{\circ} \mathrm{C}$ if the ceiling surface temperature is $20 \sim 22^{\circ} \mathrm{C}$.

\section{SIMULATION}

\subsection{HYBRID SYSTEM}

We suggested a hybrid system which is a combination of radiant cooling and low temperature air conditioning integrated with ice storage system (fig.6). A feasibility analysis determining whether this system can produce the optimum condition estimated in the experiments is simulated.

Ice storage system provides chilled water $\left(1 \sim 2^{\circ} \mathrm{C}\right)$ to an air conditioner. The air conditioner supplies low temperature and low humidity air into the ceiling. The rectangular steel air-duct isn't installed in the ceiling, and conditioned air is supplied to ceiling plenum. The conditioned air cools the ceiling surface, then is blown into the room.

\subsection{METHOD OF CALCULATONS}

The heat transfer from the conditioned air blown by the air conditioning system to the ceiling surface should be expressed as 


$$
q_{f}=A \cdot K_{f}\left(\theta_{o}-\theta_{c}\right)
$$

The heat flow when temperature of the conditioned air changes $\theta_{\mathrm{i}} \rightarrow \theta_{0}$ should be expressed as

$$
q_{f}=C_{p} \cdot \gamma \cdot V\left(\theta_{i}-\theta_{o}\right) \cdots(2)
$$

adding (1) into(2):

$$
q_{f}=K_{x c} \cdot \theta_{o}-K_{x c} \cdot \theta_{c} \cdots(3)
$$

where $K_{x c}=\frac{1}{\left(\frac{1}{A \cdot K_{f}}+\frac{1}{C_{p} \cdot \gamma \cdot V}\right)}$

Calculations of sensible heat are carried out using the equation given below,

$$
\begin{aligned}
& {\left[\begin{array}{ccccc}
A_{1} \alpha_{r}\left(1-g_{11}\right)+A_{1} \alpha_{c}+A_{1} Z_{0}+K_{x c} & -A_{1} \alpha_{r} g_{12} & \cdots & -A_{1} \alpha_{r g} g_{16} & -A_{1} \alpha_{c} \\
-A_{2} \alpha_{r} g_{21} & A_{2} \alpha_{r}\left(1-g_{22}\right)-A_{2} \alpha_{c}+A_{2} Z_{0} & \cdots & -A_{2} \alpha_{r g} g_{26} & -A_{2} \alpha_{c} \\
\cdot & \cdot & & \cdot & \cdot \\
\cdot & \cdot & & \cdot & \cdot \\
\cdot & \cdot & & -A_{5} \alpha_{r} g_{56} & -A_{5} \alpha_{c} \\
-A_{6} \alpha_{r} g_{61} & -A_{6} \alpha_{r g} g_{62} & A_{6} \alpha_{r}\left(1-g_{66}\right)+A_{6} \alpha_{c}+A_{6} Z_{0} & -A_{6} \alpha_{c} \\
A_{1} \alpha_{c}+K_{x c} & A_{2} \alpha_{c} & & A_{6} \alpha_{c} & \sum A_{j} \alpha_{c}-C_{P} \gamma V-K_{x c}
\end{array}\right]} \\
& \times\left[\begin{array}{c}
\theta_{1} \\
\theta_{2} \\
\theta_{3} \\
\theta_{4} \\
\theta_{5} \\
\theta_{6} \\
\theta_{r}
\end{array}\right]=\left[\begin{array}{c}
-A 1 \sum_{j=1}^{\infty} Z_{j} \theta_{1(k-j)}+K_{x c} \cdot t_{i} \\
-A_{2} \sum_{j=1}^{\infty} Z_{j} \theta_{2(k-j)} \\
\cdot \\
-A_{5} \sum_{j=1}^{\infty} Z_{j} \theta_{5(k-j)} \\
-A_{6} \sum_{j=1}^{\infty} Z_{j} \theta_{6(k-j)}+A_{6} \sum_{j=1}^{\infty} W_{j} \cdot g_{k-j} \\
\left(C_{p} \gamma V-K_{x c}\right) t_{i}-A_{h}
\end{array}\right] \cdots(4)
\end{aligned}
$$

Calculations of latent heat and humidity are carried out using program on coil in the air conditioner.

\subsection{RESULTS OF CALCULATIONS}

Table 4 presents comparison of room environments between radiant cooling/heating system and convectional AC. Fig.7 present peak air conditioning load.

Fig.7(a) is under radiant cooling, and fig.7(b) is under convectional AC. It is apparent from table 4 that MRT in August is $1.6^{\circ} \mathrm{C}$ lower than room temperature

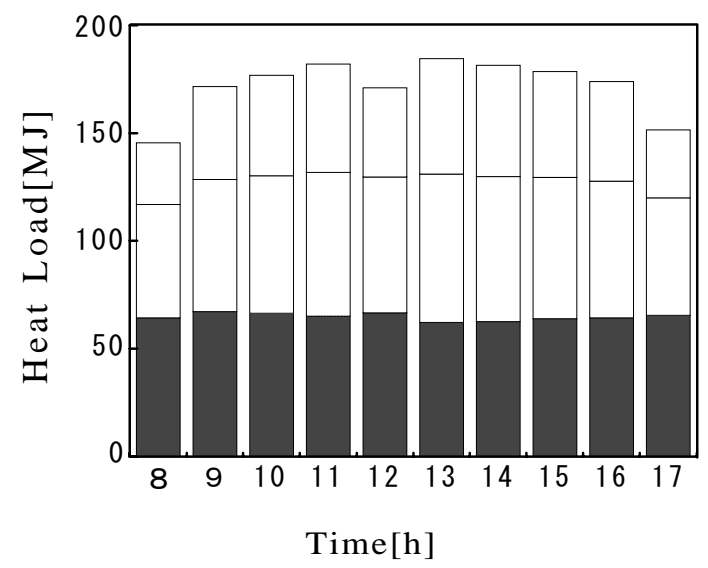

(a) Radiant Cooling

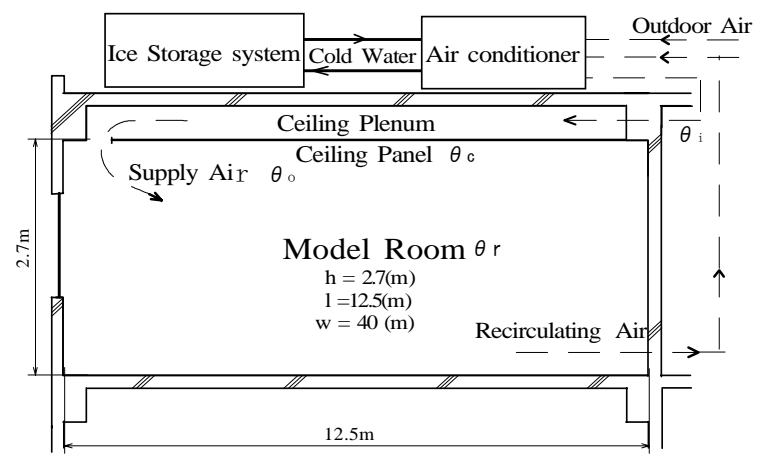

Fig.6 Hybrid System

Table 3 Nomenclature

\begin{tabular}{|c|l|}
\hline$\theta_{0}$ & Temperature of supply Air \\
\hline$\theta \mathrm{i}$ & Temperature of the Conditioned Air \\
\hline$\theta \mathrm{c}$ & Temparature of Ceiling Panel \\
\hline $\mathrm{K}_{\mathrm{f}}$ & Thermal Transmittance \\
\hline $\mathrm{C}_{\mathrm{P}}$ & Specific Heat \\
\hline $\mathrm{V}$ & Amount of Air \\
\hline $\mathrm{g}_{\mathrm{ij}}$ & Radiant Factor of Gebhart \\
\hline $\mathrm{Z}_{\mathrm{ij}}$ & Response Factor \\
\hline $\mathrm{W}_{\mathrm{j}}$ & Over Roll Thermal Transmittance \\
\hline $\mathrm{A}_{\mathrm{h}}$ & Interior Heat Load \\
\hline$\alpha_{\mathrm{r}}$ & Heat Transfer Rate of Radiation \\
\hline$\alpha \mathrm{c}$ & Heat Transfer Rate of Convection \\
\hline
\end{tabular}

under radiant cooling. On the other hand, that MRT is $1.6^{\circ} \mathrm{C}$ higher than room temperature under convectional $\mathrm{AC}$, it is found that effects from radiant cooling with cooling panels are about $3.2^{\circ} \mathrm{C}$. In June, room humidity can keep lower, so this system fits Japanese humid climate.

Fig.7(a) presents that cooling panel load is $68.7 \mathrm{MJ}$, and accounts for $56 \%$ of sensible heat load (at 13:00). In fig.7, latent heat load under radiant cooling is $68.7 \mathrm{MJ}$ compared with that under convectional AC 53.5MJ. It

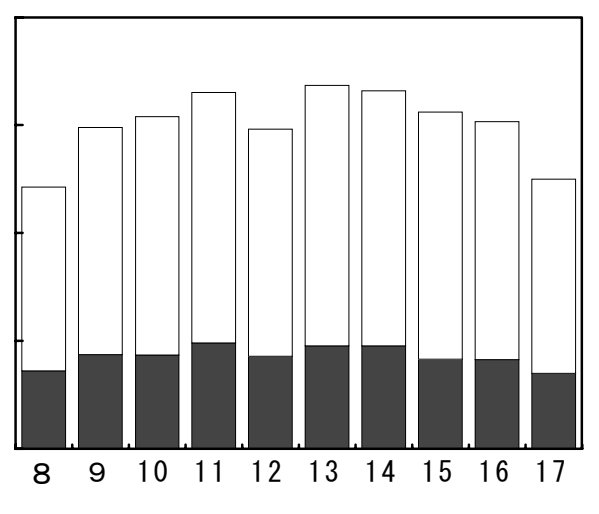

Time[h]

(b) Convectional AC

$\checkmark$ Sensible Heat Load (Air) $\square$ Sensible Heat Load (Panel) $\square$ Latent Heat Load

Fig. 7 Peak Air Conditioning Load 
Table 4 Comparison of Room Environments

\begin{tabular}{|c|c|c|c|c|c|c|c|c|c|}
\hline & System & $\begin{array}{c}\text { Outdoor Air } \\
\text { temp. } \\
\left({ }^{\circ} \mathrm{C}\right)\end{array}$ & $\begin{array}{c}\text { Outdoor } \\
\text { Humidity } \\
(\%)\end{array}$ & $\begin{array}{c}\text { Room temp. } \\
\left({ }^{\circ} \mathrm{C}\right)\end{array}$ & $\begin{array}{c}\text { Room } \\
\text { Humidity } \\
(\%)\end{array}$ & $\begin{array}{l}\text { MRT } \\
\left({ }^{\circ} \mathrm{C}\right)\end{array}$ & $\begin{array}{c}\text { Temp. of } \\
\text { Coditioned } \\
\text { Air } \\
\left({ }^{\circ} \mathrm{C}\right) \\
\end{array}$ & $\begin{array}{c}\text { Ceiling } \\
\text { Surface } \\
\text { Temp. } \\
\left({ }^{\circ} \mathrm{C}\right) \\
\end{array}$ & $\begin{array}{l}\text { OT } \\
\left({ }^{\circ} \mathrm{C}\right)\end{array}$ \\
\hline \multirow{2}{*}{ June } & Radiant & \multirow{2}{*}{23.3} & \multirow{2}{*}{69.8} & 28.0 & 37.0 & 26.4 & 11.0 & 24.9 & 27.2 \\
\hline & Convection & & & 26.0 & 61.0 & 26.7 & 19.5 & 26.4 & 26.4 \\
\hline \multirow{2}{*}{ August } & Radiant & \multirow{2}{*}{28.5} & \multirow{2}{*}{63.0} & 28.0 & 37.0 & 26.4 & 11.0 & 24.9 & 27.2 \\
\hline & Convection & & & 26.0 & 61.0 & 27.6 & 18.6 & 27.0 & 26.8 \\
\hline \multirow{2}{*}{$\begin{array}{c}\text { Peak Day of } \\
\text { Cooling } \\
\end{array}$} & Radiant & \multirow{2}{*}{31.7} & \multirow{2}{*}{60.0} & 28.0 & 37.0 & 27.3 & 11.7 & 24.8 & 27.7 \\
\hline & Convection & & & 26.0 & 58.0 & 28.2 & 117.7 & 27.4 & 27.1 \\
\hline \multirow{2}{*}{ January } & Radiant & \multirow{2}{*}{2.0} & \multirow{2}{*}{30.5} & 28.0 & 40.0 & 20.7 & 28.0 & 22.3 & 20.4 \\
\hline & Convection & & & 26.0 & 40.0 & 19.7 & 25.6 & 20.5 & 20.9 \\
\hline
\end{tabular}

is found that this system produces high efficiency of dehumidification. So this system is suit for warm and high humidity Japanese climate.

\section{COMPREHENSIVE EVALUATION OF RADIANT COOLING SYSTEM}

We study a model office building (in Tokyo, with the total floor area of $3,300 \mathrm{~m}^{2}$ ) in order to comprehesively evaluate the ice storage radiant cooling system, "radiant with ice storage", by comparison with three other cooling systems, namely, "radiant without ice storage", "convectional AC with ice storage", and "convectional AC without ice storage", as shown in Table 1. Simulations of the load leveling effect, energy saving possibility and operating cost were carried out for the four different systems. We then estimate the initial costs (construction costs) required to construct the model building with those systems.

\subsection{OPERATION OF MODEL BUILDING}

The room temperature and relative humidity settings for the office with the radiant system during the summer are $27^{\circ} \mathrm{C}$ to $28^{\circ} \mathrm{C}$ and $40 \%$, as shown on the right in
Table 5. An enivironment of those conditions is comparable to that of $26^{\circ} \mathrm{C}$ and $50 \%$ relative humidity produced by the convection system in terms of thermal sensation.

\subsection{CALCULATION OF THERMAL LOAD}

In order to determine the capacity of the heat pump and air conditioners, the hourly thermal loads in summer and winter were calculated by the response factor method under the periodic steady state using the temperatures given by the Technical Advisory Committee $(x=5.0 \%)$ for Tokyo. The same procedure was applied for each month, using each hourly outdoor design temperature, to obtain each hourly thermal load.

Table 6 presents the calculated results, including the peak values of the cooling load and the circulating air volume, which are used to determine the capacities of the air conditioning facilities.

\subsection{CALCULATION OF ELECTRICITY CONSUMPRION AND CHARGE}

In the calculation of electricity consumption, the heat gain related to piping, pumps, and fans was assumed to be $10 \%$ of the cooling load. The heat loss, $3 \%$ of the

Table 5 Cases for Comparison and Evaluation

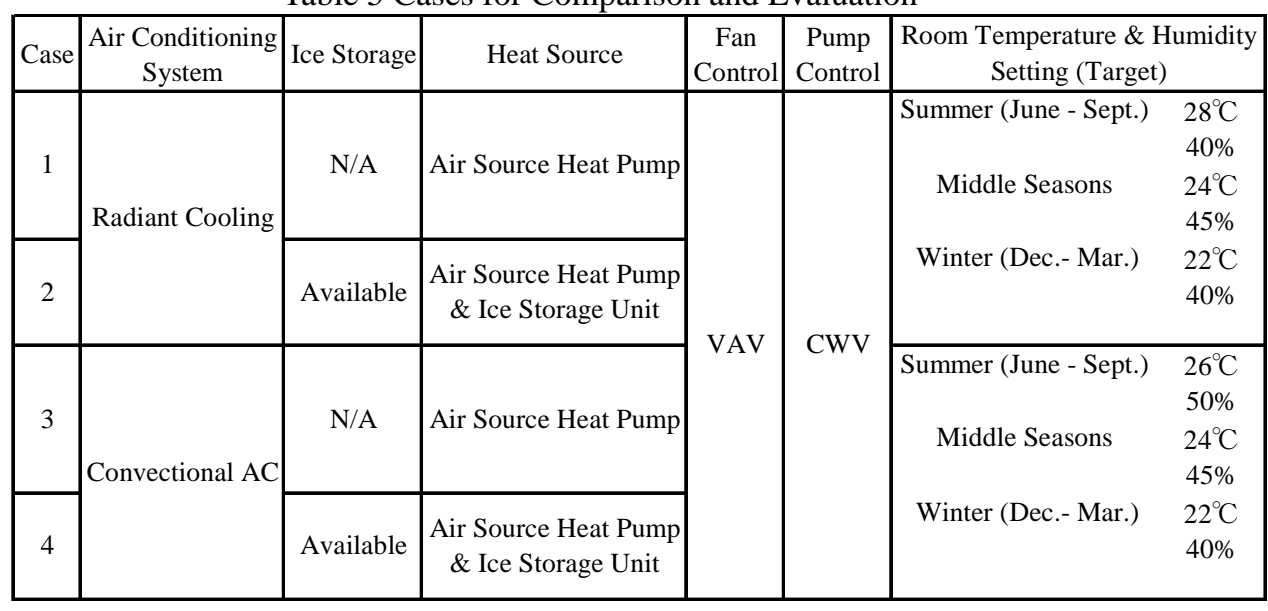


Table 6 Cooling Load and Circulating Air Volume

\begin{tabular}{|c|c|c|c|c|c|c|}
\hline \multicolumn{3}{|c|}{ Air Conditioning System } & \multicolumn{3}{|c|}{ Radiant Cooling } & Convectional AC \\
\hline Ice Storage & \multicolumn{2}{|c|}{ Room temperature Setting } & $28^{\circ} \mathrm{C}$ & $27.5^{\circ} \mathrm{C}$ & $27^{\circ} \mathrm{C}$ & $26^{\circ} \mathrm{C}$ \\
\hline N/A & \multicolumn{2}{|c|}{$\begin{array}{c}\text { Required Cooling Capacity } \\
\text { (Peak Value) }\end{array}$} & $289 \mathrm{~kW}$ & $295 \mathrm{~kW}$ & $301 \mathrm{~kW}$ & $284 \mathrm{~kW}$ \\
\hline Available & \multicolumn{2}{|c|}{$\begin{array}{l}\text { Required Stored Heat Capacity } \\
\text { for Cooling (Peak Value) }\end{array}$} & $1594 \mathrm{kWh}$ & $1635 \mathrm{kWh}$ & $1676 \mathrm{kWh}$ & $1702 \mathrm{kWh}$ \\
\hline \multirow{7}{*}{ Common } & \multirow{3}{*}{$\begin{array}{l}\text { Required } \\
\text { Circulating } \\
\text { Air Volume } \\
\end{array}$} & Office $(7 \mathrm{~F})$ & $3648 \mathrm{CMH}$ & $3823 \mathrm{CMH}$ & $4005 \mathrm{CMH}$ & $7464 \mathrm{CMH}$ \\
\hline & & Office $(2 \mathrm{~F}-6 \mathrm{~F})$ & $3049 \mathrm{CMH}$ & $3187 \mathrm{CMH}$ & $3333 \mathrm{CMH}$ & $5391 \mathrm{CMH}$ \\
\hline & & Office $(1 \mathrm{~F})$ & $2962 \mathrm{CMH}$ & $3096 \mathrm{CMH}$ & $3238 \mathrm{CMH}$ & $5192 \mathrm{CMH}$ \\
\hline & \multirow{4}{*}{$\begin{array}{c}\text { Required } \\
\text { Cooling } \\
\text { Capacity for } \\
\text { Sensible Heat } \\
\text { (Peak Value) }\end{array}$} & $\begin{array}{l}\text { Circulation } \\
\text { Space }(7 \mathrm{~F})\end{array}$ & \multicolumn{4}{|c|}{$4.6 \mathrm{~kW}$} \\
\hline & & $\begin{array}{c}\text { Circulation } \\
\text { Space }(2 \mathrm{~F}-6 \mathrm{~F})\end{array}$ & \multicolumn{4}{|c|}{$2.8 \mathrm{~kW}$} \\
\hline & & $\begin{array}{l}\text { Circulation } \\
\text { Space }(1 \mathrm{~F}) \\
\end{array}$ & \multicolumn{4}{|c|}{$2.3 \mathrm{~kW}$} \\
\hline & & Entrance Hall & \multicolumn{4}{|c|}{$12.1 \mathrm{~kW}$} \\
\hline
\end{tabular}

total thermal load, was also considered for the ice storage tank.

The electricity rates of Tokyo Electric Power Co. for a thermal storage system for commercial use, effective January 1, 1996, was used for the calculation. An $80 \%$ discount is applicable to the rates for the heat pump for thermal storage in the nighttime (10 P.M. to 8 A.M.).

\subsection{RESULTS OF ENERGY CALCULATION}

Fig.8 presents the mothly electricity consumption and breakdown for the radiant cooling systems. A comparison of fig. 8 shows the reduction in the electricity consumption of the heat pump during the daytime due to the thermal storage.

\subsubsection{Comparison between radiant and convection systems}

Using the ice storage radaiant cooling system, the maximum power demand, the annual electricity consumprion and charges equivalent to, or slightly less than, those of the convection system are possible, as seen in table 7(1), (2),(3). Without the ice storage system, the maximum power demand and the annual electricity consumption for the radiant system is expected to increase approximately $10 \%$ over those of the convectional $\mathrm{AC}$.

\subsubsection{Comparison between cases with and without} ice storage, for radiant system

With ice storage, the maximum power demand for radiant cooling can be reduced by $34 \%$ at maximum during the summertime as compared to the case without ice storage, as shown in table 7(1). The annual elec-
Table 7 Comprehensive Evaluation Results ( $¥: J P Y$ )

\begin{tabular}{|c|c|c|c|}
\hline \multirow{2}{*}{$\begin{array}{c}\text { Air Conditioning } \\
\text { System }\end{array}$} & \multicolumn{2}{|c|}{ Ice Storage } & \multirow{2}{*}{ Difference } \\
\hline & N/A & Available & \\
\hline \multicolumn{4}{|c|}{ (1) Maximum Power Demand } \\
\hline Radiant & $219 \mathrm{~kW}$ & $144 \mathrm{~kW}$ & $\begin{array}{l}-75 \mathrm{~kW} \\
(-34 \%)\end{array}$ \\
\hline Convectional AC & $194 \mathrm{~kW}$ & $151 \mathrm{~kW}$ & $\begin{array}{l}-43 \mathrm{~kW} \\
(-22 \%)\end{array}$ \\
\hline Difference & $\begin{array}{l}+25 \mathrm{~kW} \\
(+13 \%)\end{array}$ & $\begin{array}{l}-7 \mathrm{~kW} \\
(-5 \%) \\
\end{array}$ & \\
\hline \multicolumn{4}{|c|}{ (2) Annual Electricity Consumption } \\
\hline Radiant & $401 \mathrm{MWh}$ & $362 \mathrm{MWh}$ & $\begin{array}{c}-39 \mathrm{MWh} \\
(-10 \%)\end{array}$ \\
\hline Convectional AC & $370 \mathrm{MWh}$ & $371 \mathrm{MWh}$ & $\begin{array}{c}+1 \mathrm{MWh} \\
(0 \%)\end{array}$ \\
\hline Difference & $\begin{array}{c}+31 \mathrm{MWh} \\
(+8 \%)\end{array}$ & $\begin{array}{c}-9 \mathrm{MWh} \\
(-3 \%) \\
\end{array}$ & \\
\hline \multicolumn{4}{|c|}{ (3) Running Cost (Annual Electricity Charges) } \\
\hline Radiant & $¥ 10.0 \mathrm{M}$ & $¥ 7.0 \mathrm{M}$ & $\begin{array}{c}-¥ 2.9 \mathrm{M} \\
(-29 \%)\end{array}$ \\
\hline Convectional AC & $¥ 9.1 \mathrm{M}$ & $¥ 7.2 \mathrm{M}$ & $\begin{array}{c}-¥ 1.8 \mathrm{M} \\
(-20 \%)\end{array}$ \\
\hline Difference & $\begin{array}{c}+¥ 0.9 \mathrm{M} \\
(+10 \%)\end{array}$ & \begin{tabular}{|c|}
$-¥ 0.2 \mathrm{M}$ \\
$(-3 \%)$ \\
\end{tabular} & \\
\hline \multicolumn{4}{|c|}{ (4) Initial Cost (Construction Cost) } \\
\hline Radiant & $¥ 800.7 \mathrm{M}$ & $¥ 812.9 \mathrm{M}$ & $\begin{array}{c}+¥ 12.1 \mathrm{M} \\
(+1.5 \%)\end{array}$ \\
\hline Convectional AC & $¥ 794.0 \mathrm{M}$ & $¥ 810.4 \mathrm{M}$ & $\begin{array}{c}+¥ 16.4 \mathrm{M} \\
(+2.1 \%)\end{array}$ \\
\hline Difference & $\begin{array}{l}+6.7 \mathrm{M} \\
(+0.8 \%) \\
\end{array}$ & $\begin{array}{c}+¥ 2.4 \mathrm{M} \\
(+0.3 \%) \\
\end{array}$ & \\
\hline
\end{tabular}

(5) Simple Years to Payback (Relative to "Convection without Ice Storage")

\begin{tabular}{|c|c|c|c|c|}
\hline \multirow{2}{*}{$\begin{array}{c}\text { Air Conditioning } \\
\text { System }\end{array}$} & Ice Storage & \multicolumn{2}{|c|}{ Difference } & Simple \\
Initial Cost & $\begin{array}{c}\text { Running } \\
\text { Cosst }\end{array}$ & $\begin{array}{c}\text { Years to } \\
\text { Payback }\end{array}$ \\
\hline \multirow{2}{*}{ Radiant } & N/A & $+¥ 6.7 \mathrm{M}$ & $+¥ 0.9 \mathrm{M}$ & - \\
\cline { 2 - 4 } & Available & $+¥ 18.8 \mathrm{M}$ & $-¥ 2.0 \mathrm{M}$ & 9.3 years \\
\hline \multirow{2}{*}{ Convectional AC C } & N/A & - & - & - \\
\cline { 2 - 4 } & Available & $+¥ 16.4 \mathrm{M}$ & $-¥ 1.8 \mathrm{M}$ & 9.0 years \\
\hline
\end{tabular}

tricity consumption can also be reduced by $10 \%$, as shown in table 6(2). At the current electricity rate, $29 \%$ of the charges can be saved, as shown in table 7(3). The ratio of the annual electricity consumption of the heat 


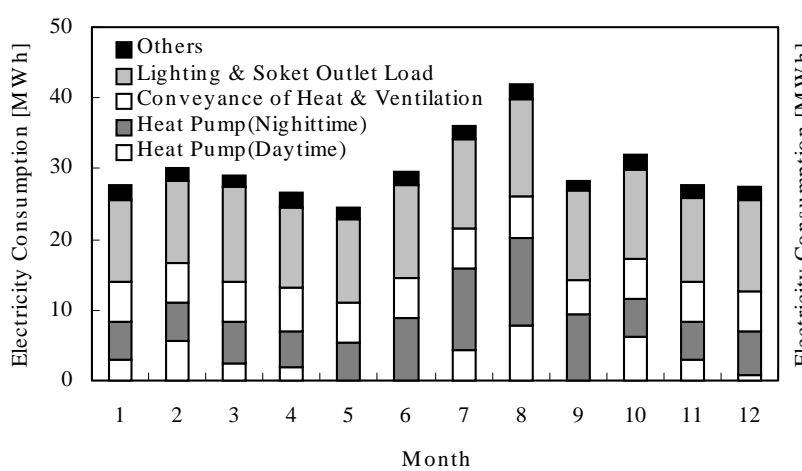

(a) with Ice Storage

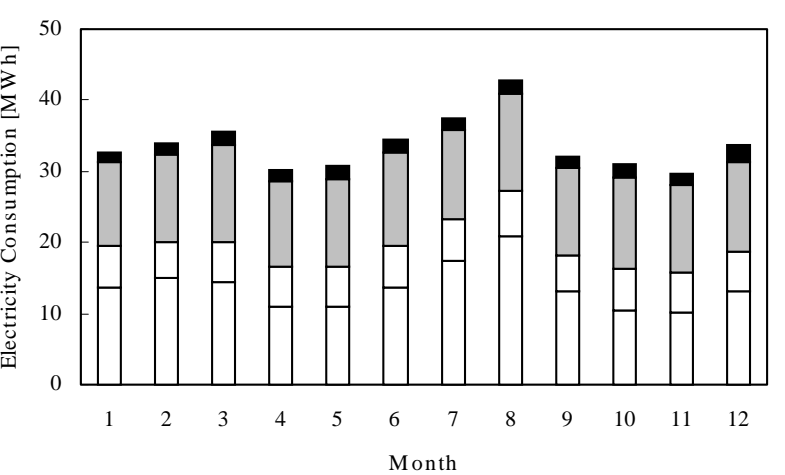

(b) without Ice Storage

Fig.8 Monthly Electricity Consumption and Breakdown (Radiant System)

pump during the nighttime to the total consumption is expected to be $72 \%$.

\subsection{ESTIMATE RESULTS OF INITIAL COST}

The initial cost for "radiant with ice storage”, $¥$ $812.86 \mathrm{M}$, proved to be $¥ 8.84 \mathrm{M}$ (2.4\%) more expensive than that for "convection with ice storage”, ¥ 794.02M. However, comparing "radiant with ice storage”, with “convection with ice storage” ( $¥ 810.43 \mathrm{M})$, the cost was only slightly increased, by $¥ 2.43 \mathrm{M}(0.3 \%)$, as also shown in table 7(4).

\subsubsection{Interior finishing}

The first row in table 8 presents the items of interior finishing related to the difference in the estimates. For the radiant system, aluminum panels are used for the ceiling radiant panels. For the convection system, sound - absorbing rock wool boards are used. Consequently, the cost for the radiant system is $¥ 14.00 \mathrm{M}$ more.

\subsubsection{Electric equipment}

The contract maximum power demand differs de-

Table 8 Factors Affecting Construction Cost ( $¥: J P Y)$

\begin{tabular}{|c|c|c|c|c|}
\hline & \multicolumn{2}{|c|}{ Items which Cause Difference } & \multirow[b]{2}{*}{ Difference } \\
\hline & & \multirow{2}{*}{\begin{tabular}{c|} 
Radiant with Ice \\
Storage \\
Ceiling Radinat Panel \\
Aluminm Panel \\
$2417 \mathrm{~m}^{2}$ \\
Foamed Styrence Board \\
$2077 \mathrm{~m}^{2}$ \\
\end{tabular}} & \multirow{2}{*}{\begin{tabular}{|c|}
$\begin{array}{c}\text { Convection with Ice } \\
\text { Storage }\end{array}$ \\
Sound - Absorbing \\
Rock Wool Board \\
$2075 \mathrm{~m}^{2}$
\end{tabular}} & \\
\hline $\begin{array}{l}\text { (a) Interior } \\
\text { Finishing }\end{array}$ & Ceiling & & & $+¥ 14.00 \mathrm{M}$ \\
\hline $\begin{array}{l}\text { (b) Electric } \\
\text { Equipment }\end{array}$ & $\begin{array}{l}\text { Substation \& } \\
\text { Main Feeder }\end{array}$ & \begin{tabular}{|c|} 
Constract Maximum \\
Power Demand 144kW
\end{tabular} & $\begin{array}{c}\text { Constract Maximum } \\
\text { Power Demand } 151 \mathrm{~kW}\end{array}$ & - ¥0.90 M \\
\hline \multirow{2}{*}{$\begin{array}{c}\text { (c) Air } \\
\text { Conditionin } \\
\text { g Facility }\end{array}$} & $\begin{array}{c}\text { Air } \\
\text { Conditioner \& } \\
\text { Installation }\end{array}$ & $\begin{array}{c}\text { Air Conditioners } \\
3600 \mathrm{CMH} \times 6 \text { Units } \\
4800 \mathrm{CMH} \times 1 \text { Units } \\
\text { Installation Expenses }\end{array}$ & $\begin{array}{c}\text { Air Conditioners } \\
6000 \mathrm{CMH} \times 6 \text { Units } \\
9000 \mathrm{CMH} \times 1 \text { Units } \\
\text { Installation Expenses }\end{array}$ & - $¥ 5.20 \mathrm{M}$ \\
\hline & $\begin{array}{c}\text { Duct \& } \\
\text { Installation }\end{array}$ & $\begin{array}{c}\text { Duct } 210 \mathrm{~m}^{2} \\
\text { Air Outlet 27Units } \\
\text { Volume Damper } 39 \\
\text { Other Material Costs } \\
\text { Installation Expenses }\end{array}$ & $\begin{array}{c}\text { Duct } 644 \mathrm{~m}^{2} \\
\text { Air Outlet 54Units } \\
\text { Volume Damper } 66 \\
\text { Other Material Costs } \\
\text { Installation Expenses }\end{array}$ & - $¥ 5.40 \mathrm{M}$ \\
\hline & Total & $¥ 262.80 \mathrm{M}$ & $¥ 260.40 \mathrm{M}$ & $+¥ 2.40 \mathrm{M}$ \\
\hline
\end{tabular}

pending on the air conditioning system and whether or not ice storage is provided. This difference is reflected in the estimates of substation and main feeder. It produces a difference of $¥ 0.90 \mathrm{M}$ for the electric equipment between "radiant with ice storage" and "convection with ice storage", as shown in the second row of table 8.

\subsubsection{Air conditioning facility}

The section area of the duct was calculated based on the circulating air volume in each case, and then the required area of the duct was determined. The number of volume dampers required was determined by adding 12 to the number of air outlets. These values are summarized in the third row of table 8 to illustrated the difference. In total, the air conditioning facility for "radiant with ice storage” proved to be $¥ 10.60 \mathrm{M}$ more expensive than that for "convection with ice storage".

\subsubsection{Years to payback}

Table 7(5) presents the simple years to payback relative to "convection without ice storage". Both "radiant with ice storage" and "convection with ice storage" are calculated to require nine years to payback. Under the assumption that ice storage is adopted for load leveling, the difference between the two systems with ice storage is negligible.

\section{CONCLUSIONS}

In this paper, we estimated the optimum room condition by mesurements of the thetmal environment and experiments with subjects, and suggested a hybrid system which is a radiant cooling system using conditioned air as a refrigerant integrated with ice storage system. This system 
can provide more comfortable room environment than convectional AC. The results of calculations show that ice storage system make the effedt of dehumidification higher, and prevent from the occurrence of condensation.

Using ice storage radiant cooling system, both the maximum power demand and the annual electricity consumption equivalent to or slightly less than those of the covection system can be achieved. Under the assumption that is exposed to be approximately $¥ 2.40 \mathrm{M}$ over that for the convection system.

\section{REFERENCES}

1. Motoyasu Sasaki. "A Study on Thermal Comfort by Radiant Cooling from Ceiling", The Society of Heating, Air-Conditioning and Sanitary Engineers of Japan(SHASE). 1990.

2. Hiromitsu Izumi. "Low Temperature Air Conditioning System”, SHASE. 1993.

3. Sadahiko Suzuki. "Study on Ice Storage Air Conditioning System - Part10 12 Thermal Sensation Analysis of Low Humidity and High Temperature Airconditoned Space", Summaries of Techinical Paper of Annual Meeting, Architectural Institute of Japan. 19891991.

4. Masaya Okumiya. "Room Environment under Low Temperature air Delivery Ice Storage”, SHASE. 1996.

5. Kenichi Kimura. "Fundamental Theories of Building Services", pp.274-279.

6. ASHRAE STANDARD, "Thermal Environmental Conditions for Human Occupancy", ANSI / ASHRAE 55-1981.

7. Y.Nagata, "Future Prospect of Power Demand and Supply in Japan”, OHM, June 1995, pp.54-57. (in Japanese).

8. L. G. Berglund, "Comfort Benefits for Summer Air Conditioning with Ice Storage", ASHRAE Transactions, Vol. 1 97, part 1, 1991, pp.843-847.

9. R. W. Kulpmann, “Thermal Comfot and Air Quality in Rooms with Cooled Ceilings - Results of Scientific Investigations", ASHRAE Transactions, Vol. 99, part 2, 1993, pp.488-502.

10. P. Simmonds, "Practical Applications of Radiant Heating and Cooling to Maintain Comfort Conditions", ASHRAE Transactions, Vol. 102, part 1, 1996, pp.659666.
11. G. Zweifel and M. Koschenz, "Simulation of Displacement Ventilation and Radiant Cooling with DOE2", ASHRAE Transactions, Vol. 99, part 2, 1993, pp.548-555.

12. C. Setiu, H. E. Feustel and F. C. Winkelmann, “Development of a Model to Simulate the Performance of Hydronic Radiant Cooling Ceilings", ASHRAE Transactions, Vol. 101, part 2, 1995, pp.730-743.

13. C. M. Landry and C. D. Noble, "Case Study of Cost - Effectiveness Low - Temperature Air Distribution, Ice Thermal Storage", ASHRAE Transactions, Vol. 97, part 1, 1991, pp.854-859.

14. M. F. Brunk, "Cooling Ceiling - An Opportunity to Reduce Energy Costs by Way of Radiant Cooling”, ASHRAE Transactions, Vol. 99, part 2, 1993, pp.479487.

15. T. W. Brady, "Achieving Energy Conservation with Ice - Based Thermal Storage", ASHRAE Transactions, Vol. 100, part 1, 1994, pp.1735-1745.

16. U. Inoue and H. Lee, "Simulation of Cooling Coil and Simplified Calculation Method (part 1)", Proceeding of SHASE, 1981, pp.197-200. (in Japanese)

17. Financial Investigation Society, "Data Book for Estimation", September 1997. (in Japanese)

18. Financial Investigation Society, "Estimating for Building Works", November 1992. (in Japanese)

19. Management Research Society for Construction Industry, "MRC: 95 Cost Analysis Information for Building Works", Taisei Publishing Co., April 1997. (in Jpanese) 